\title{
Essential Role of the Main Olfactory System in Social Recognition of Major Histocompatibility Complex Peptide Ligands
}

\author{
Marc Spehr, ${ }^{1 *}$ Kevin R. Kelliher, ${ }^{1 *}$ Xiao-Hong Li, ${ }^{1}$ Thomas Boehm, ${ }^{2}$ Trese Leinders-Zufall, ${ }^{1}$ and Frank Zufall ${ }^{1}$ \\ ${ }^{1}$ Department of Anatomy and Neurobiology, University of Maryland School of Medicine, Baltimore, Maryland 21201, and ${ }^{2}$ Department of Developmental \\ Immunology, Max Planck Institute of Immunobiology, D-79108 Freiburg, Germany
}

\begin{abstract}
Genes of the major histocompatibility complex (MHC), which play a critical role in immune recognition, influence mating preference and other social behaviors in fish, mice, and humans via chemical signals. The cellular and molecular mechanisms by which this occurs and the nature of these chemosignals remain unclear. In contrast to the widely held view that olfactory sensory neurons (OSNs) in the main olfactory epithelium (MOE) are stimulated by volatile chemosignals only, we show here that nonvolatile immune system molecules function as olfactory cues in the mammalian MOE. Using mice with targeted deletions in selected signal transduction genes (CNGA2, CNGA4), we used a combination of dye tracing, electrophysiological, $\mathrm{Ca}^{2+}$ imaging, and behavioral approaches to demonstrate that nonvolatile MHC class I peptides activate subsets of OSNs at subnanomolar concentrations in vitro and affect social preference of male mice in vivo. Both effects depend on the cyclic nucleotide-gated (CNG) channel gene CNGA2, the function of which in the nose is unique to the main population of OSNs. Disruption of the modulatory CNGA4 channel subunit reveals a profound defect in adaptation of peptide-evoked potentials in the MOE. Because sensory neurons in the vomeronasal organ (VNO) also respond to MHC peptides but do not express $C N G A 2$, distinct mechanisms are used by the mammalian main and accessory olfactory systems for the detection of MHC peptide ligands. These results suggest a general role for MHC peptides in chemical communication even in those vertebrates that lack a functional VNO.
\end{abstract}

Key words: main olfactory epithelium; olfactory sensory neuron; odor transduction; chemosignal; social recognition; MHC

\section{Introduction}

Social behavior in vertebrates is influenced by the highly polymorphic genes of the major histocompatibility complex (MHC). In addition to their established role in the adaptive immune response, MHC genes are thought to give rise to odor signals that carry information about individuality (Wedekind et al., 1995; Penn and Potts, 1998; Reusch et al., 2001; Jacob et al., 2002; Beauchamp and Yamazaki, 2003). The cellular and molecular mechanisms by which this occurs and the molecular nature of these chemosignals remain unclear. Current models consider MHC molecules or their fragments, degradation products of their peptide ligands, or products of the MHC-dependent microflora as potential odorants (Penn and Potts, 1998; Beauchamp and Yamazaki, 2003).

We have focused our attention on a mechanism in which the

Received Sept. 1, 2005; revised Jan. 5, 2006; accepted Jan. 6, 2006

This work was supported by the Emmy Noether Program (M.S.) and the Leibniz Program (T.B.) of the Deutsche Forschungsgemeinschaft and by grants from the National Institutes of Health-National Institute on Deafness and Other Communication Disorders (K.R.K., T.L.-Z., and F.Z.). We thank R. Escher for peptide synthesis; R. Reed for providing knock-out mice; A. Puche, M. Shipley, and J.Ziesmann for valuable contributions during the early phase of the development of the MOE slice preparation; and D. E. Pankevich for training in the surgical removal of the VNO.

*M.S. and K.R.K. contributed equally to this work.

Correspondence should be addressed to Dr. Marc Spehr, Department of Anatomy and Neurobiology, University of Maryland School of Medicine, 20 Penn Street, Baltimore, MD 21201. E-mail: mspeh001@umaryland.edu. DOI:10.1523/JNEUROSCI.4939-05.2006

Copyright $\odot 2006$ Society for Neuroscience $\quad$ 0270-6474/06/261961-10\$15.00/0 small nonvolatile peptide ligands of MHC molecules function directly as chemosignals. The molecular properties of these MHC peptides are ideal to encode information about individuality (i.e., MHC genotype), because peptide sequences directly reflect the structure of MHC molecules (Rammensee et al., 1997). In mice, chemical signals are recognized by at least two anatomically and functionally distinct sensory organs, the main olfactory epithelium (MOE) and the vomeronasal organ (VNO) (Buck, 2000; Firestein, 2001; Brennan and Keverne, 2004; Mombaerts, 2004; Restrepo et al., 2004). We found previously that MHC class I peptides activate sensory neurons in the $\mathrm{VNO}$ (Leinders-Zufall et al., 2004), which has traditionally been thought to transduce appropriate chemosignals after direct contact with the stimulus source (Halpern, 1987; Meredith, 1991). However, there is considerable evidence that the main olfactory system also participates in MHC-related behaviors (Penn and Potts, 1998; Beauchamp and Yamazaki, 2003). Much, but not all, of this previous literature used tests that required the chemosignal(s) to be volatile. If MHC peptides are part of a general mechanism enabling reliable sensing of genotypic information via the nose, we might hypothesize that these molecules are also detected by the main olfactory system. Here, we ask the following: (1) Does the MOE, which is widely believed to recognize only airborne volatiles, mediate the detection of nonvolatile molecules of the immune system? (2) And if so, does this involve an evolutionary 
conserved transduction mechanism? (3) Or is the specialized VNO the only mammalian sense organ that mediates social recognition of MHC peptide ligands?

To address these questions, which are of importance for understanding the general organization and evolution of chemical communication in mammals, we apply a combination of dye tracing, electrophysiological, imaging, and behavioral methods in wild-type (WT) and gene-targeted mice. With this approach, we provide compelling evidence that peptide ligands can be recognized by the mammalian MOE via an evolutionary conserved cAMP-dependent signaling pathway and that this information is used for social decision making in behavioral situations involving direct physical contact. These results open new perspectives for the function of the mammalian main olfactory system in the detection of social recognition signals.

\section{Materials and Methods}

Animals. Mice were housed in micro-isolator cages on a $12 \mathrm{~h} \mathrm{light/dark}$ cycle with food and water available ad libitum. Electrophysiological experiments used young adults of either sex. We did not observe any obvious differences between males and females in peptide-evoked potentials in the MOE. For behavioral analysis, 52 sexually naive male mice (40 C57BL/6 and $12 \mathrm{BALB} / \mathrm{c}$ mice) were purchased (Charles River Laboratories, Wilmington, MA) and singly housed. Mice deficient for CNGA2 $\left(C N G A 2^{-10}\right.$ males; $C N G A 2^{-1-}$ females; the disrupted CNGA2 allele tagged with a tau-lacZ reporter) or CNGA4 and their WT littermate controls were bred as described previously (Zhao and Reed, 2001; Munger et al., 2001). Both lines were maintained in a mixed SvJ/129 $\times$ $\mathrm{C} 57 \mathrm{BL} / 6$ background $\left(\mathrm{H}-2 \mathrm{D}^{\mathrm{b}}\right.$ haplotype). If not stated otherwise, data are recorded from at least three different animals and expressed as means \pm SD. All procedures were approved by the Institutional Animal Care and Use Committee of the University of Maryland School of Medicine.

Chemicals. Nine different MHC peptides were used in this study. Peptides were designed according to known binding specificities of MHC class I molecules, synthesized, purified, verified by mass spectrometry (matrix-assisted laser desorption ionization-time of flight), dissolved in PBS (1-10 mM), stored frozen, and diluted to the final concentration in extracellular bath solution (see below) immediately before use (LeindersZufall et al., 2004). 2-Heptanone (Fluka, Neu-Ulm, Germany), free amino acids (Sigma, St. Louis, MO), and other pharmacological agents [2-aminoethoxydiphenyl borate (2-APB; Calbiochem, La Jolla, CA), SQ22536 (Calbiochem), and MDL12330A (Sigma)] were prepared according to the manufacturer's instructions.

Electrophysiology. We used the submerged field potential recording technique as described previously for mouse MOE whole-organ preparations (Chen et al., 2000; Munger et al., 2001). Briefly, mice were anesthetized, decapitated, and hemisected, and the nasal septum was removed to expose the endoturbinate system of the MOE. The tissue was superfused continuously at room temperature with oxygenated solution ( $95 \% \mathrm{O}_{2} / 5 \% \mathrm{CO}_{2}$ ) containing (in $\left.\mathrm{mM}\right) 120 \mathrm{NaCl}, 25 \mathrm{NaHCO}_{3}, 5 \mathrm{KCl}, 5$ $\mathrm{BES}$ [ $N, N$-bis(2-hydroxyethyl)-2-aminoethanesulfonic acid], $1 \mathrm{MgSO}_{4}$, $1 \mathrm{CaCl}_{2}$, and $10 \mathrm{~mm}$ glucose. Peptides were focally ejected using single- or multi-barrel stimulation pipettes. The interstimulus interval was $4 \mathrm{~min}$. Stimulus concentration refers to the concentration in the stimulation pipette. Glass pipettes (resistance, 1-3 M $\Omega$; tips filled with HEPESbuffered extracellular solution in $1.5 \%$ agar) (Leinders-Zufall et al., 2000) connected via an $\mathrm{Ag} / \mathrm{AgCl}$ wire to a differential amplifier (DP-301; Warner Instruments, Hamden, CT) were placed onto the MOE surface. A second $\mathrm{Ag} / \mathrm{AgCl}$ wire connected to an agar bridge served as the indifferent electrode. Amplifier output signals were digitized, low-pass filtered (eight-pole Bessel; corner frequency, $1 \mathrm{kHz}$; digital filter frequency, $60 \mathrm{~Hz}$ ), and analyzed on-line using Pulse software (HEKA Elektronik, Lambrecht/Pfalz, Germany). Compared with conventional electroolfactogram (EOG) recording, a main advantage of this method is that it is independent of the volatility of a given stimulus and allows for application of pharmacological agents without altering the thickness of the aqueous layer covering the epithelium. We established this method previously by using conventional odor ligands (Chen et al., 2000) and showed that the adaptational properties of signals recorded in this way depend on the CNGA4 channel subunit, providing direct evidence that the measured responses reflect second-messenger signaling in the olfactory cilia (Munger et al., 2001). We performed these experiments using highly localized, aqueous micropulse stimuli that prevent prestimulation of the sensory tissue and allow for spatial mapping of sensitive epithelial spots. Therefore, the size of the recorded field potentials is somewhat smaller compared with classical EOG recordings that use vapor-phase stimulation methods. Activation of the transduction pathway in a nonreceptor-mediated manner (i.e., by using the phospodiesterase inhibitor IBMX) has allowed for some normalization of our method (Munger et al., 2001).

Confocal calcium imaging in MOE slices. Acute MOE tissue slices were prepared from postnatal C57BL/6 mice [postnatal day 1 (P1) to P9] of either sex. Bone formation prevented slicing in older animals. The anterior aspect of the head containing the olfactory sense organs and the olfactory bulb was embedded in agarose $(5 \%)$ and placed in ice-cold oxygenated solution, and coronal slices $(300 \mu \mathrm{m})$ were cut using a vibratome (Ziesmann et al., 2002). Intracellular $\mathrm{Ca}^{2+}$ was monitored with fluo-4/AM (Molecular Probes, Eugene, OR) using a Bio-Rad (Hercules, CA) Radiance 2100 confocal laser system [fitted to an Olympus (Tokyo, Japan) BX51WI microscope; 20× water immersion objective] (LeindersZufall et al., 2000, 2004). Fluo-4/AM was dissolved in a solution consisting of DMSO and 20\% Pluronic F-127 (Molecular Probes), which was then added to the oxygenated solution, sonicated briefly, and added to the experimental chamber to yield a final concentration of $4.6 \mu \mathrm{M}$ fluo4/AM, $0.01 \%$ Pluronic F- 127 , and $0.1 \%$ DMSO. Slices were incubated in this solution for $60-75 \mathrm{~min}$ at $37^{\circ} \mathrm{C}$ using an $\mathrm{O}_{2} / \mathrm{CO}_{2}$ incubator (Binder, Tuttlingen, Germany), washed with dye-free solution for $10 \mathrm{~min}$, and superfused continuously $(100 \mu \mathrm{l} / \mathrm{s})$ at room temperature with oxygenated solution for the duration of the experiment. Images were acquired at $0.5 \mathrm{~Hz}$ with an optical thickness of $\sim 10 \mu \mathrm{m}$ and analyzed using NIH Image 1.63, ImageJ 1.32, and Igor Pro software (WaveMetrics, Lake Oswego, OR). Peptides were added for $10 \mathrm{~s}$ to the superfusing bath solution (laminar flow chamber).

Access of nonvolatiles to the MOE. Female urine (30 $\mu \mathrm{l})$ was supplemented with the nonvolatile molecule rhodamine 6G (0.01\%; Sigma) (Wysocki et al., 1980; Leinders-Zufall et al., 2004). Urine drops were placed either on a male's oronasal groove (ONG) or on the skin in the anogenital region (AGR) of an estrous female while animals were freely investigating each other. Male mice were killed after $3 \mathrm{~min}$ and decapitated, and their endoturbinates were exposed as described above. Images were taken using a Nikon (Tokyo, Japan) SMZ 1500 stereomicroscope equipped with fluorescence epi-illumination and a DsRed filter set.

VNO removal. The VNO was surgically removed in adult male C57BL/6 mice (Wysocki and Wysocki, 1995; Pankevich et al., 2004). After anesthesia, animals were placed supine in a head holder. The lower jaw was gently opened allowing access to the soft palate. Using a scalpel, an incision was made along the midline of the soft palate from the first to the third palatal ridge. In sham-operated animals, the incision was then closed. For VNO removal (VNX) animals, the vomer bones were opened ventrally, and the VNO was removed bilaterally. The resulting cavity was filled with gel foam, and the incision was closed using absorbable sutures. Animals were monitored carefully after surgery for bleeding and/or breathing difficulties and allowed at least 1 week of recovery.

After behavioral testing of VNX mice, the accessory olfactory bulbs of all animals were analyzed histologically to verify the complete removal of the VNO (Wysocki and Wysocki, 1995; Pankevich et al., 2004). Mice were deeply anesthetized with pentobarbital $(50 \mathrm{mg} / \mathrm{kg})$ and perfused transcardially with $0.1 \mathrm{M}$ PBS containing $0.001 \%$ heparin, followed by PBS containing 4\% paraformaldehyde (PFA). Brains containing olfactory bulbs were carefully removed, postfixed for $2 \mathrm{~h}$ (4\% PFA), and cryoprotected overnight at $4^{\circ} \mathrm{C}$ using PBS containing 30\% sucrose. Using a cryostat, $20 \mu \mathrm{m}$ tissue slices were cut, collected on gelatin-coated slides, incubated in PBS containing $1 \% \mathrm{H}_{2} \mathrm{O}_{2}$ for $2 \mathrm{~h}$, washed in $0.1 \mathrm{M}$ PBS four times for $10 \mathrm{~min}$, and stained with horseradish peroxidase-conjugated soybean agglutinin (HRP-SBA; $15 \mu \mathrm{g} / \mathrm{ml}$, Sigma). After another wash in 

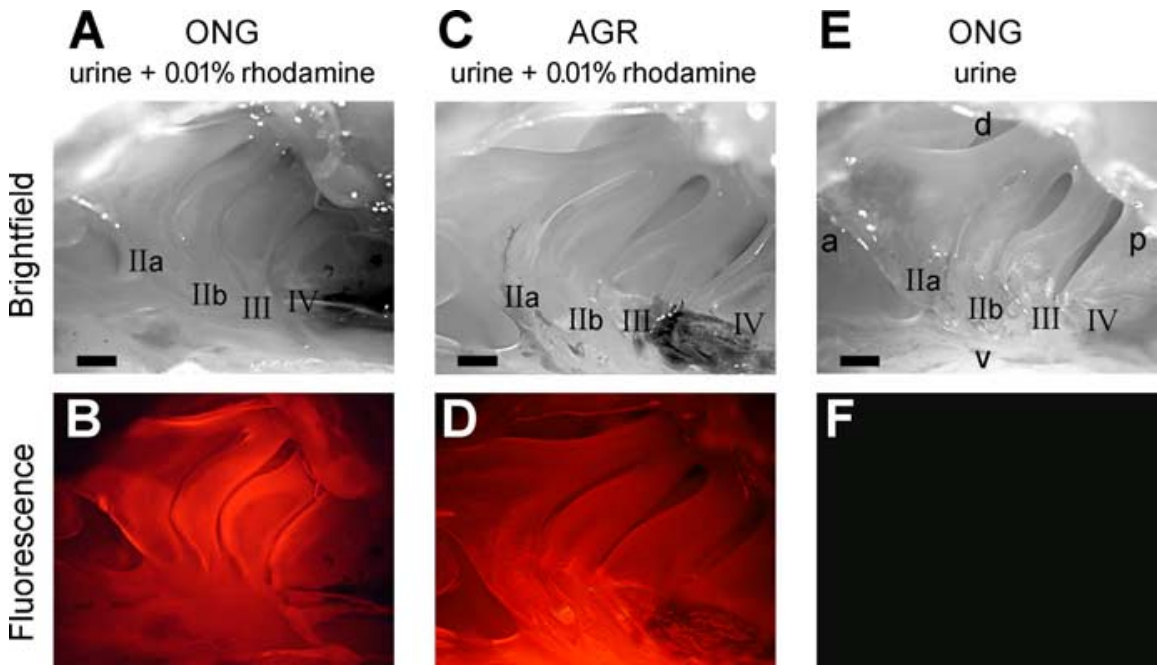

Figure 1. Nonvolatile molecules gain access to the mouse $M O E$ after direct contact with the stimulus source. $\boldsymbol{A}-\boldsymbol{F}$, Bright-field $(\boldsymbol{A}, \boldsymbol{C}, \boldsymbol{E})$ and fluorescence images $(\boldsymbol{B}, \boldsymbol{D}, \boldsymbol{F})$ showing the dissected endoturbinate system of male $C 57 \mathrm{BL} / 6 \mathrm{mice}$. Female urine was placed on a male's oronasal groove (ONG) $(\boldsymbol{A}, \boldsymbol{B}, \boldsymbol{E}, \boldsymbol{F})$ or in the anogenital region (AGR) of an estrous female, and males were allowed to freely investigate $(\boldsymbol{C}, \boldsymbol{D})$. When the urine contained the nonvolatile rhodamine dye $(0.01 \%)$, rhodamine fluorescence was visible on all four endoturbinates $(\boldsymbol{B}, \boldsymbol{D})$, whereas control animals treated with rhodamine-free urine did not show such fluorescence $(\boldsymbol{F})$. Fluorescence images in $\boldsymbol{B}, \boldsymbol{D}$, and $\boldsymbol{F}$ were taken under identical optical conditions. No significant autofluorescence was observed at this wavelength. All of these experiments used VNX mice. Roman numerals designate individual turbinates. $a$, Anterior; p, posterior; d, dorsal; v, ventral. Scale bars, $500 \mu \mathrm{m}$.

PBS, tissue slices were reacted with nickel-intensified diaminobenzidine (Vector Laboratories, Burlingame, CA) and counterstained for Nissl substance with cresyl violet.

Behavioral testing. We analyzed social preference in male mice by giving them a choice to freely investigate two different MHC peptide mixtures presented in an identical female self-strain urinary background. Tests were performed in each subject's home cage. Peptide- urine mixtures $(25 \mu \mathrm{l})$ were pipetted on either of two cotton-tipped applicators that were placed in a randomized manner in adjacent corners of the cage ("cotton-tip test"). For each strain (C57BL/6, BALB/c, or SvJ/129 × C57BL/6), urine was collected and pooled from 15 female mice at various stages of estrus and frozen until use. To study MHC peptide preferences, haplotype-specific peptide mixtures $\left(\mathrm{H}-2 \mathrm{~K}^{\mathrm{d}}\right.$ haplotype: SYFPEITHI, SYIPSAEKI, SFVDTRTLL; H-2D ${ }^{\mathrm{b}}$ haplotype: AAPDNRETF, ASNENMETM, FAPGNYPAL) or PBS alone (solvent) were added to the urine samples (1:20, v/v; final peptide concentration, $12.5 \mu \mathrm{M}$ each) (LeindersZufall et al., 2004). In one set of experiments, we also used peptides at 10-fold lower concentrations (supplemental Fig. 8, available at www. jneurosci.org as supplemental material). The exact concentration of MHC peptide ligands in urine is currently unknown (see Discussion). On the basis of the known concentration of soluble MHC molecules present in the serum and urine of rodents (Singh et al., 1987), the concentration of endogenous MHC peptide ligands in the extracellular compartment can be estimated to be at least $10^{-8} \mathrm{M}$. It is unknown whether these peptides exist in free or bound form. We took into account the possibility that carrier proteins (other than MHC) present in bodily secretions might be necessary to deliver the peptides to the olfactory mucosa in behaving mice. To displace endogenous peptides from such putative carrier molecules, peptides were added at a concentration equivalent to a 100 - to 1000-fold molar excess, assuming that $K_{\mathrm{d}}$ values for these complexes are in the same range as those of MHC class I/peptide complexes (Dedier et al., 2001) and that only a small fraction of the fluid applied to the cotton tip will be taken up and further diluted in the mucus.

All mice showed a keen interest in investigating the stimulus source with intense periods of sniffing, during which their noses were in direct physical contact with the cotton tips (see supplemental movie 1, available at www.jneurosci.org as supplemental material). As a control, we performed one set of experiments under conditions in which mice were intentionally prevented from coming into physical contact with the stimulus source (see Fig. $6 D$, caged stimuli). In these experiments, cotton tips were placed in meshed, plastic cassette cages (Jet Cassette; Leica, Nussloch, Germany) that prevented direct physical access to urine stimuli. Preferences reported here were calculated as a percentage of time (mean \pm SEM) spent investigating the cotton tips during a 5 min period. Tests were videotaped, and behavior was analyzed using Observer Video-Pro software (Noldus Information Technology, Wageningen, The Netherlands). In all experiments, the investigator was blind to the identity of the peptide stimulus as well as the genotype/surgical condition of the test animal. Preferences for each stimulus were compared using one-way or two-way repeated-measures ANOVA, followed by Student-Newman-Keuls post hoc analysis.

\section{Results \\ Nonvolatile molecules gain access to the MOE}

Social investigation in mice involves periods of robust physical contact between conspecifics, during which intense sniffing and licking of facial and anogenital areas occurs. We hypothesized that nonvolatile chemostimuli may gain access to the MOE during such behaviors. To test this, we used a dye-tracing approach (Wysocki et al., 1980; Leinders-Zufall et al., 2004). Female urine was supplemented with the nonvolatile fluorescent dye rhodamine, and a drop was placed on a male's ONG. Alternatively, the urine-rhodamine mixture was placed in the AGR of an estrous female, and males were allowed to freely investigate. After sniffing or anogenital investigation, we examined rhodamine fluorescence in the nasal cavity. To exclude false-positive results attributable to preparational artifacts (i.e., crushing or squeezing the dye-containing VNO), we used mice that had their VNOs surgically removed (VNX) (Wysocki and Wysocki, 1995; Pankevich et al., 2004). Both placement on the ONG (Fig. 1A,B) and application to a female's AGR (Fig. $1 C, D$ ) caused strong rhodamine fluorescence throughout the endoturbinate system of the MOE. The same results were observed in mice that had not undergone surgery. However, such fluorescence was never observed when normal rhodamine-free urine was used (Fig. 1E,F). These results reveal that nonvolatile compounds present in urine and other bodily secretions gain access to the MOE during behavioral situations involving direct physical contact.

\section{MHC class I peptides are potent stimuli for sensory neurons in the MOE}

Murine MHC class I peptide ligands are nonvolatile molecules, typically nine amino acid residues long, that are presented by MHC molecules at the cell surface. When peptide/MHC complexes are released into the extracellular space and appear in urine and other bodily secretions (Singh et al., 1987), any information contained in their chemical complexity becomes a property of the entire individual (Boehm et al., 2003; Boehm and Zufall, 2005). Given the results of our dye-tracing studies (Fig. 1), these peptides could potentially function as social recognition signals detected by the MOE. Are MHC peptides thus capable of stimulating sensory neurons in mouse MOE? To examine this question, we recorded local field potentials (the EOG) from the ciliated surface of the MOE using methods that do not require olfactory stimuli to be volatile (Chen et al., 2000; Munger et al., 2001) and tested whether known peptide ligands of MHC class I molecules 
A

\begin{tabular}{|c|c|c|c|}
\hline $\begin{array}{l}\text { inbred } \\
\text { strain }\end{array}$ & $\begin{array}{c}\mathrm{MHC} \\
\text { molecule }\end{array}$ & sequence & description \\
\hline C57BL/6 & $\mathrm{H} 2-\mathrm{D}^{\mathrm{b}}$ & $\begin{array}{l}\text { AAPDNRETF } \\
\text { AAPDARETA } \\
\text { ANPRAFDTE }\end{array}$ & $\begin{array}{l}\text { minor } \mathrm{H} \mathrm{Ag} \mathrm{(H7} \mathrm{locus);} \mathrm{origin:} \mathrm{unknown} \\
\text { mutated form } \\
\text { scrambled version of AAPDNRETF }\end{array}$ \\
\hline $\mathrm{BALB} / \mathrm{c}$ & $\mathrm{H} 2-\mathrm{K}^{\mathrm{d}}$ & $\begin{array}{l}\text { SYFPEITHI } \\
\text { SAFPEITHA }\end{array}$ & $\begin{array}{l}\text { origin: Jak } 1 \mathrm{TK} \\
\text { mutated form }\end{array}$ \\
\hline
\end{tabular}

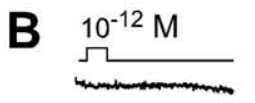

AAPDNRETF
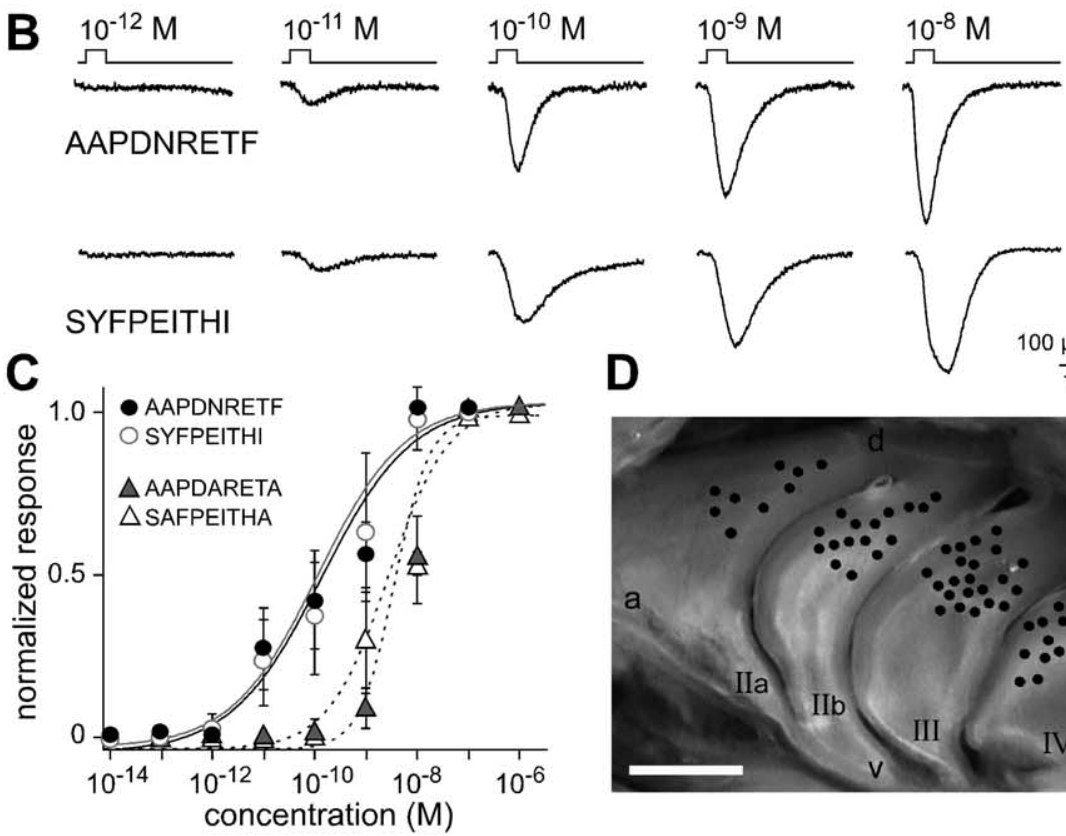

E
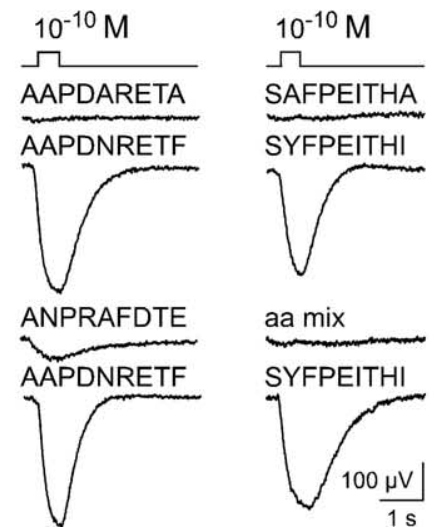

$\mathbf{F}$

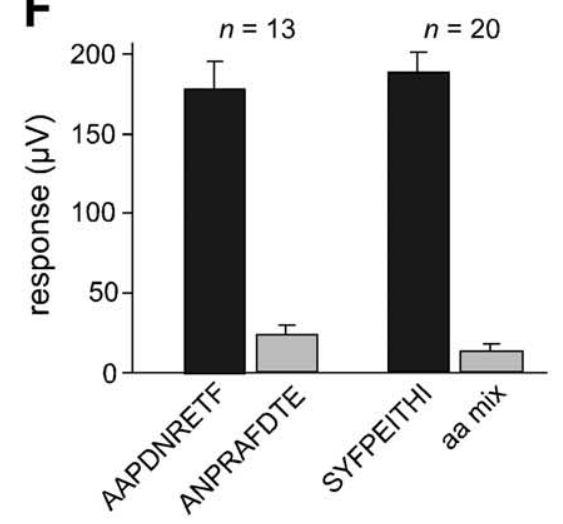

Figure 2. The mouse MOE detects MHC class I peptide ligands. $\boldsymbol{A}$, Peptide ligands for prototypical representatives of MHC class I molecules used in this study. Sequences (in one-letter code) and sources were taken from Rammensee et al. (1997), which provides detailed primary references. Anchor residues defining haplotype-specific binding characteristics are highlighted in bold, and mutated residues in control peptides are underlined. In the ANPRAFDTE peptide, anchor positions 5 and 9 of the WT peptide were replaced with residues unfavorable for binding to the $D^{b}$ MHC molecule (Rammensee et al., 1997), whereas the overall amino acid composition remains identical. minor $\mathrm{H} \mathrm{Ag}$, Minor histocompatibility antigen; TK, tyrosine kinase. $\boldsymbol{B}$, Examples of peptide-evoked MOE field potentials and their dose dependence (each series from a single location) to varying concentrations of either AAPDNRETF (representative of 43 recordings in 5 animals) or SYFPEITHI (representative of 38 recordings in 12 animals). Responses are produced by $500 \mathrm{~ms}$ pulses of peptides as indicated. C, Average dose-response plots of peak responses to AAPDNRETF (filled circles, black curve) and SYFPEITHI (open circles, red curve). The results for two control peptides, AAPDARETA (solid triangles) and SAFPEITHA (open triangles), respectively, are also shown. Smooth curves are fitted by the Hill equation, with $K_{1 / 2}$ values and Hill coefficients of 190 pm, 0.6 (SYFPEITHI); 240 pm, 0.6 (AAPDNRETF); 5.4 nm, 0.8 (SAFPEITHA); and 8.3 nм, 1.3 (AAPDARETA). D, Medial view of the mouse endoturbinate system after dissection. Roman numerals designate individual turbinates. Sixty spatial locations of 96 spots stimulated that exhibited a field potential response to AAPDNRETF and/or SYFPEITHI at $10^{-10} \mathrm{M}$ are shown. The other 36 locations that did not respond are included in the map in Figure $3 A$, which documents the entire elicit an electrical response in olfactory sensory neurons (OSNs). We chose peptides that prototypically correspond to two disparate $\mathrm{H}-2$ haplotypes (Leinders-Zufall et al., 2004), namely AAPDNRETF (for the $\mathrm{H}-2 \mathrm{D}^{\mathrm{b}}$ haplotype of C57BL/6 mice) and SYFPEITHI (for the unrelated $\mathrm{H}-2 \mathrm{~K}^{\mathrm{d}}$ haplotype of BALB/c mice) (Fig. $2 A$ ). Both representative peptides evoked negative field potentials in a dose-dependent manner in the MOE of male and female C57BL/6 mice carrying the $\mathrm{H}-2 \mathrm{D}^{\mathrm{b}}$ haplotype (Fig. $2 \mathrm{~B}$ ), suggesting that cognate MHC class I molecules are not required for this response. For both peptides, we found detection thresholds at concentrations near or below $10^{-11} \mathrm{M}$ (Fig. $2 B, C$ ). These results reveal an exquisite sensitivity of the mouse MOE for MHC class I peptides.

For comparison, we tested the effect of the urinary volatile 2-heptanone, one of the prospective pheromones that act as sensory cues in both the MOE and VNO (Leinders-Zufall et al., 2000; Boschat et al., 2002; Ziesmann et al., 2002; Xu et al., 2005), and found that this stimulus also elicits MOE field potentials at $10^{-10} \mathrm{M}$ (Figs. 3B, 4C). Likewise, other urinary volatile chemosignals such as 2,5-dimethylpyrazine, 2-sec-butyl-4,5-dihydrothiazole, 2,3-dehydroexo-brevicomin, and 6-hydroxy-6-methyl-3heptanone are capable of evoking sensory responses at subnanomolar concentrations in the MOE (Ziesmann et al., 2002) as well as the VNO (Leinders-Zufall et al., 2000).

Figures $2 D$ and 3 examine the spatial distribution of peptide responses in the MOE in more detail. We sequentially stimulated 96 different locations on all four endoturbinates with AAPDNRETF and SYFPEITHI as well as 2-heptanone (each at $10^{-10} \mathrm{M}$ ). By superimposing the locations of peptide-evoked potentials onto a bright-light image of the MOE, we produced coarse maps of the spatial organization of peptide sensitivity (Figs. 2D, 3A). Of these 96 locations, 54\% (52 of 96) responded to the $\mathrm{D}^{\mathrm{b}}$ ligand, and $60 \%$ (58 of

\section{$\leftarrow$}

data set. Scale bar, $1000 \mu \mathrm{m} . \boldsymbol{E}, \boldsymbol{F}$, Specificity of peptideevoked MOE field potentials assessed by two control peptides in which the characteristic anchor residues of MHC class I ligands were replaced by alanines [i.e., AAPDARETA (8 recordings, 3 animals) and SㅌFPEITHA (14 recordings, 4 animals), respectively]. These peptides failed to elicit a field potential at $10^{-10} \mathrm{M}(\boldsymbol{E})$. A scrambled version of the $\mathrm{H} 2-\mathrm{D}^{\mathrm{b}}$ ligand AAPDNRETF, ANPRAFDTE $\left(10^{-10} \mathrm{M}\right)$, and a mixture containing all amino acids (aa mix; in free form, each at $10^{-10} \mathrm{M}$ ) that constitute the SYFPEITHI peptide elicited only very small or no responses $(\boldsymbol{E}, \boldsymbol{F})$. Each pair of responses in $\boldsymbol{E}$ corresponded to the same spatial location. Error bars indicate SEM. 

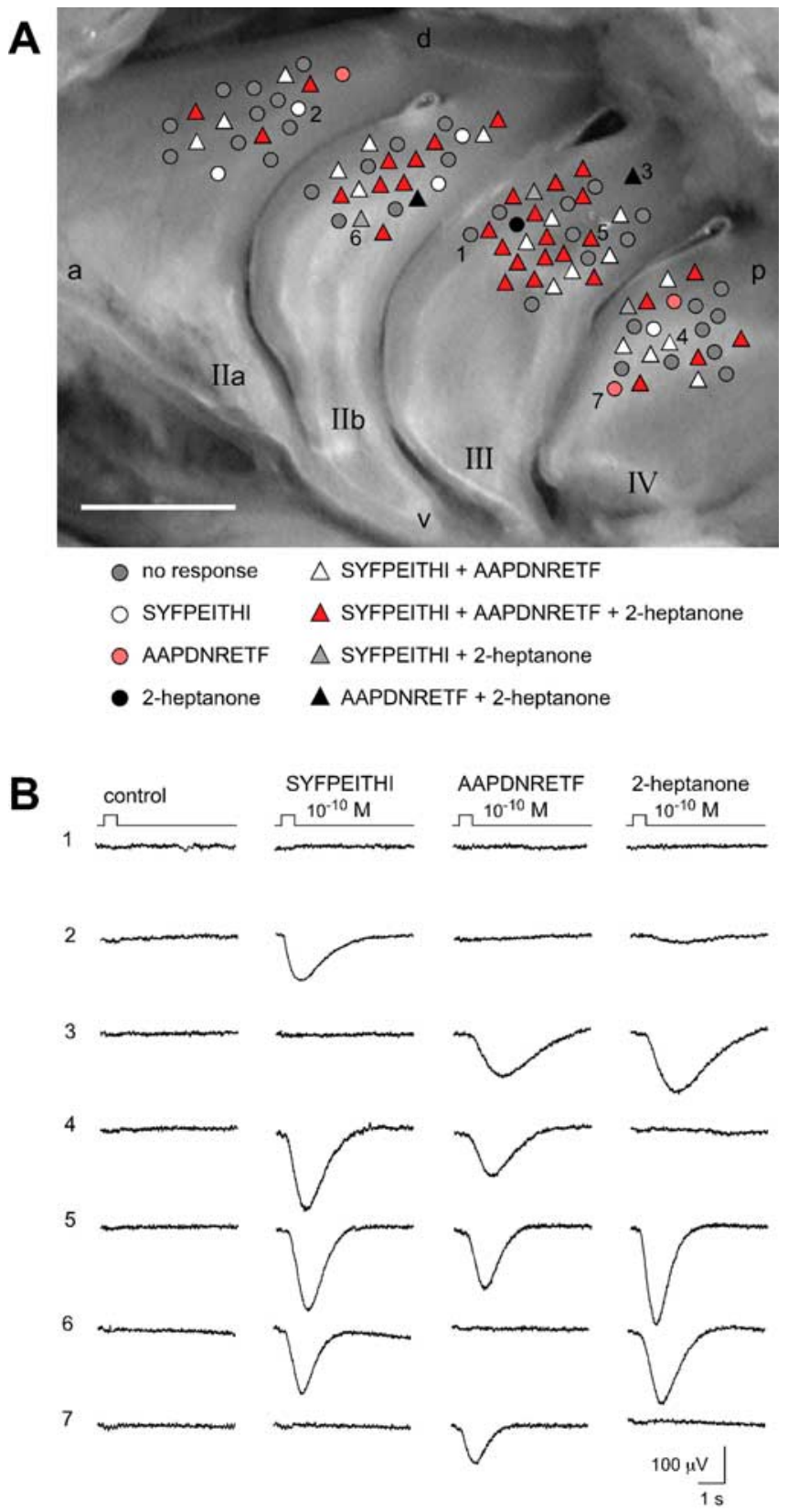

C. Frequency of observing a field potential response on a given endoturbinate
\begin{tabular}{|c|c|c|c|c|}
\hline $\begin{array}{l}\text { Endo- } \\
\text { turbinate }\end{array}$ & $\mathrm{n}$ & $\begin{array}{c}\text { SYFPEITHI } \\
10^{-10} \mathrm{M}\end{array}$ & $\begin{array}{c}\text { AAPDNRETF } \\
10^{-10} \mathrm{M}\end{array}$ & $\begin{array}{c}\text { 2-heptanone } \\
10^{-10} \mathrm{M}\end{array}$ \\
\hline \hline IIa & 19 & $7(37 \%)$ & $6(32 \%)$ & $2(11 \%)$ \\
IIb & 22 & $15(68 \%)$ & $12(55 \%)$ & $9(41 \%)$ \\
III & 32 & $23(72 \%)$ & $23(72 \%)$ & $18(56 \%)$ \\
IV & 23 & $13(57 \%)$ & $11(48 \%)$ & $6(26 \%)$ \\
\hline
\end{tabular}

Figure 3. Spatial distribution of peptide-evoked field potentials on endoturbinates Ila, Ilb, III, and IV. A, Map of 96 spatial locations that were stimulated sequentially with AAPDNRETF, SYFPEITHI, and 2-heptanone (each at $10^{-10} \mathrm{M}$ ). Color-coded symbols indicate whether a given location responded to none, one, two, or all three of these stimuli. Scale bar, $1000 \mu \mathrm{m} . \boldsymbol{B}$, Examples of field potential responses registered in different locations. The numerals (1-7) refer to a given location as shown in $\boldsymbol{A}$. Ejecting bath solution (control) onto the MOE gave no responses. $C$, Analysis of the data shown in $A$ with respect to the frequency of observing a response to each of the three ligands (at $10^{-10} \mathrm{M}$ ) on a given endoturbinate $(n$, number of locations tested on each turbinate).
96) responded to the $\mathrm{K}^{\mathrm{d}}$ ligand (Fig. 3A-C). 2-Heptanone evoked field potentials in 37\% (35 of 96) of these locations (Fig. 3A-C). Collectively, these results demonstrate that sensitive peptide recognition is widely distributed in the MOE and occurs on all four endoturbinates. The fact that some locations showed a high sensitivity whereas others did not respond to these stimuli (Fig. 3B) is broadly consistent with the mosaic organization of the mouse MOE as reported by Ma and Shepherd (2000).

To assess the specificity of peptide detection by the MOE, we used two mutated control peptides. In these ligands, the characteristic anchor residues, which fit into specific binding pockets of the MHC molecule and are thus a defining feature of an MHC peptide (Rammensee et al., 1997), were replaced by alanines (i.e., AAPDARETA and SAFPEITHA, respectively). These peptides failed to elicit MOE responses at $10^{-10} \mathrm{M}$ (Fig. $2 \mathrm{E}$ ) and showed dose-response curves that are shifted to higher concentrations by approximately two logarithmic units (Fig. 2C). Furthermore, a scrambled version of the $\mathrm{H}-2 \mathrm{D}^{\mathrm{b}}$ ligand AAPDNRETF, $\mathrm{AN}$ PRAFDTE $\left(10^{-10} \mathrm{M}\right)$, and a mixture containing all amino acids (in free form, each at $10^{-10} \mathrm{M}$ ) that constitute the SYFPEITHI peptide elicited only very small or no responses (Fig. 2E,F). Thus, peptides must meet precise structural specifications to induce low-threshold activation of sensory neurons in the MOE.

\section{Peptide detection by the MOE requires canonical cAMP signaling}

To begin to identify the cellular and molecular mechanisms underlying peptide detection by the MOE, we next asked whether the canonical cAMP second-messenger system found in the main population of OSNs (Firestein, 2001; Zufall and Munger, 2001) is required for peptide-evoked field potentials. Using SYFPEITHI $\left(10^{-10} \mathrm{M}\right)$ as a stimulus, we found that responses are inhibited in a reversible manner by application of an antagonist of adenylyl cyclase, SQ22536 (Chen et al., 2000) (300 $\mu \mathrm{M})$ (Fig. 4A,B). Another adenylyl cyclase antagonist, MDL12330A (Chen et al., 2000) $(50 \mu \mathrm{M})$, produced very similar results indicating that cAMP formation is required for these responses (Fig. $4 \mathrm{~B}$ ). In contrast, 2-APB (50 $\mu \mathrm{M})$, which blocks $\mathrm{Ca}^{2+}$-permeable, diacylglycerol-activated cation channels essential for VNO transduction and inhibits peptide-evoked potentials in the VNO (Lucas et al., 2003; Leinders-Zufall et al., 2004), did not significantly reduce the size of peptide-induced MOE responses (Fig. $4 B$ ). Hence, MHC class I peptides are detected in the MOE by sensory neurons using transduction mechanisms that are distinct from those in the VNO.

To further support this notion, we next recorded MOE field potentials from mice exhibiting targeted deletions in specific genes essential for cAMP-dependent sensory transduction in OSNs. Results were compared with those from WT littermates. Mice deficient for CNGA2 (Zhao and Reed, 2001), which encodes the principal subunit of the olfactory cyclic nucleotide-gated $(\mathrm{CNG})$ cation channel, failed to respond to SYFPEITHI $\left(10^{-10}\right.$ M; $n=26$ ) (Fig. 4C,D). The same result was obtained when we used AAPDNRETF $\left(10^{-10} \mathrm{M} ; n=12\right)$ (data not shown) or 2-heptanone $\left(10^{-10} \mathrm{M} ; n=12\right)$ (Fig. $\left.4 C\right)$ as stimuli. If peptideevoked EOG responses are mediated by signal transduction events in the main population of OSNs, these responses should not only depend on CNGA2 but also be impaired in $C N G A 4^{-1-}$ mice, which lack a modulatory subunit of the olfactory CNG channel and exhibit specific defects in odor adaptation (Munger et al., 2001; Kelliher et al., 2003). Indeed, peptide-evoked potentials from $C N G A 4^{-1-}$ MOE displayed a characteristic reduction in the desensitization rate compared with those from WT mice 
(Fig. 4E-G). Hence, we conclude that MHC class I peptides, in the MOE, are transduced by OSNs using a cAMPsignaling pathway and the canonical olfactory CNG channel.

\section{Single peptide-sensitive OSNs in MOE slices}

Next, we investigated peptide recognition in the MOE at the single-cell level by using an in situ $\mathrm{Ca}^{2+}$ mapping approach (Ziesmann et al., 2002). Acute coronal MOE slices (C57BL/6 mice) were loaded with the $\mathrm{Ca}^{2+}$ indicator fluo-4/AM and imaged at an optical resolution sufficient to detect responses in single OSNs (Fig. 5). Stimulation with AAPDNRETF or SYFPEITHI (each at $10^{-9} \mathrm{M}$ ) produced transient increases in intracellular $\mathrm{Ca}^{2+}$ in specific subsets of OSNs when tested in such slices (Fig. 5A-D). Peptide-sensitive cells were widely distributed in the MOE and found in the epithelium covering the dorsal recess (Fig. $5 A, C$ ), endoturbinates I and IIa, and ectoturbinates 1 and 2 . In total, we imaged 890 OSNs (13 slices, 8 mice), of which 26 cells $(2.9 \%)$ responded to either of these two peptides. In contrast to previous findings in the VNO (Leinders-Zufall et al., 2004), we did not observe cells that responded to both of these two peptides. Of these 890 OSNs, 16 (1.8\%) responded to the $\mathrm{D}^{\mathrm{b}}$ ligand and 10 responded $(1.1 \%)$ to the $\mathrm{K}^{\mathrm{d}}$ ligand. After peptide stimulation, we applied the adenylyl cyclase activator forskolin $(20 \mu \mathrm{M})$ to demonstrate that peptide-sensitive OSNs exhibit a cAMP-dependent $\mathrm{Ca}^{2+}$ rise (Fig. $\left.5 D\right)(n=$ 12 ), consistent with the results described in Figure 4.

To further investigate sequencespecific tuning of individual OSNs, we used the scrambled peptide ANPRAFDTE and the two mutated peptides AAPDARETA and SAFPEITHA (each at $10^{-9} \mathrm{M}$ ) in a portion of our imaging experiments $(n=246$ cells) (Fig. 5D). Although we did not observe any response to ANPRAFDTE or SAFPEITHA, twothirds (six of nine) of the AAPDNRETF-sensitive cells produced a small but significant $\mathrm{Ca}^{2+}$ transient to AAPDARETA (Fig. 5D, cells 1 and 2). This result is not only consistent with the field potential recordings in Figure $2 C$ but also demonstrates that at least some OSNs are capable of recognizing multiple peptides exhibiting different anchor residues. Hence, peptide recognition in the MOE likely occurs in a combinatorial manner.

\section{MOE-dependent peptide detection in behaving mice}

To determine the biological implications of our findings, we investigated whether behaving mice are capable of recognizing MHC peptides through their MOE and whether they might assign meaning to this information in appropriate social behaviors. Because the main olfactory system plays an important role in attracting males to females (Keverne, 2004), we tested social pref- erence by giving sexually naive male mice a choice between pairs of identical female same-strain urine that were supplemented with different haplotype-specific MHC class I peptide mixtures. Stimuli were pipetted on either of two cotton-tipped applicators that were placed in a randomized manner in adjacent corners of the cage (cotton-tip test; see Materials and Methods). All mice showed a keen interest in investigating the stimulus source with intense periods of sniffing, during which their noses were in direct physical contact with the cotton tips (see supplemental movie 1, available at www.jneurosci.org as supplemental material). Preferences were calculated as a percentage of time (mean \pm SEM) spent investigating the cotton tips during a 5 min test period. The histogram in Figure $6 \mathrm{~A}$ shows that the average investigation time is relatively maintained throughout this test.

To check for the validity of the assay, we first tested whether C57BL/6 males show a preference when presented with unaltered urine from either $\mathrm{C} 57 \mathrm{BL} / 6$ or $\mathrm{BALB} / \mathrm{c}$ females. We found that 

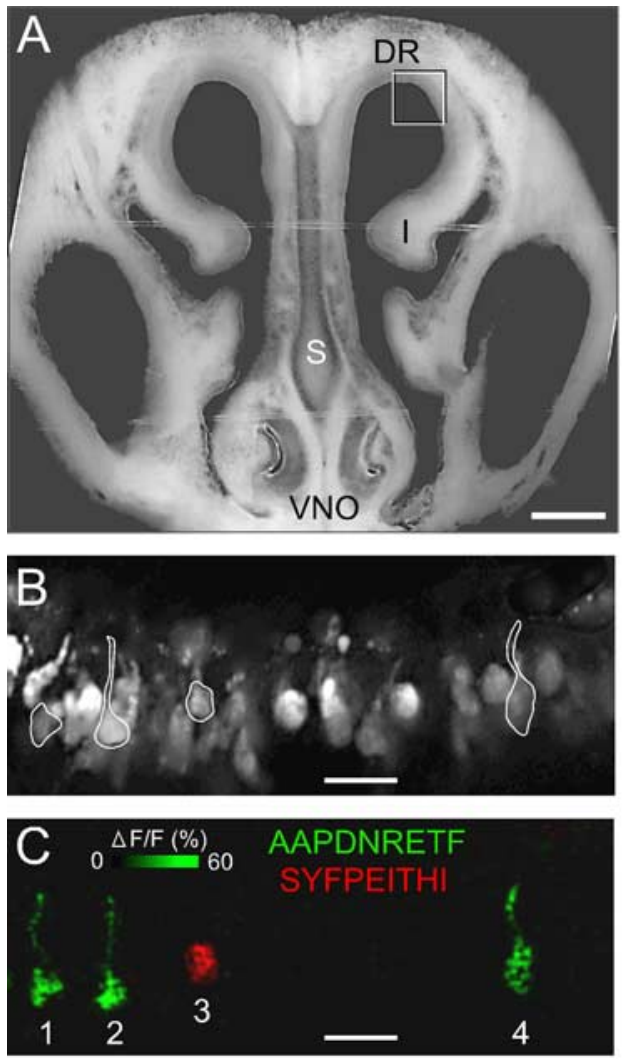

Cell 1 Cell 2 Cell 3 Cell 4 AAPDNRETF
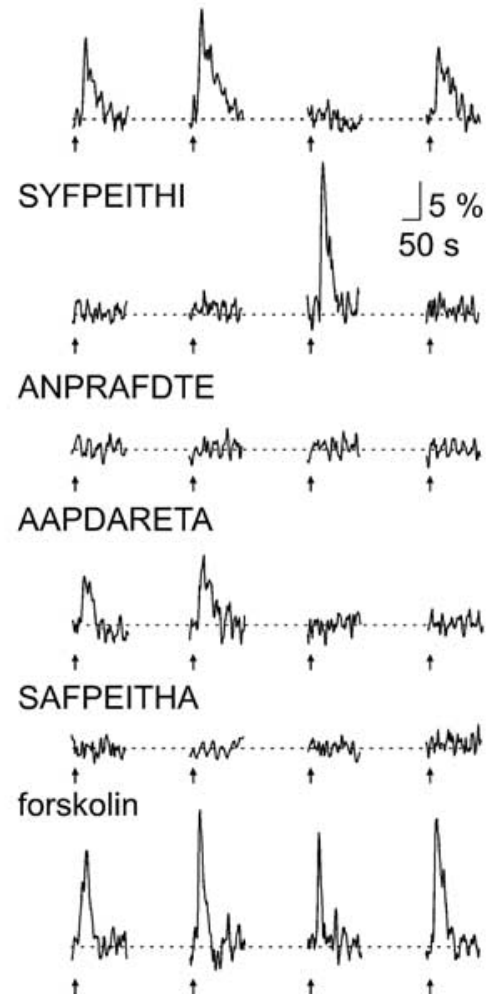

Figure 5. In situ $\mathrm{Ca}^{2+}$ mapping reveals distinct populations of peptide-sensitive OSNs. $A$, Transmitted light image of a mouse coronal MOE slice (P7). DR, Dorsal recess; $S$, nasal septum. A portion of the sensory epithelium delimited by the white box is shown at a higher magnification in $\boldsymbol{B}$ and $\boldsymbol{C}$. $\boldsymbol{B}$, Confocal fluorescence image of the fluo-4-loaded MOE acquired at rest (grayscale). $\boldsymbol{C}$, The same region is depicted as a merged pseudocolor image of the relative increase in peptide-induced $\mathrm{Ca}^{2+}$-dependent dye fluorescence (ratio between the peak fluorescence before and after stimulation, $\Delta \mathrm{F} / \mathrm{F})$. In this example, AAPDNRETF $\left(10^{-9} \mathrm{M}\right.$; green) activated three OSNs (cells 1, 2, and 4), and SYFPEITHI ( $\left(10^{-9} \mathrm{M}\right.$; red) activated one OSN (cell 3). In some cases, individual somata, dendrites, and dendritic knobs can be clearly distinguished. $\boldsymbol{D}$. Time course of peptide-induced $\mathrm{Ca}^{2+}$ responses from the same cells that are shown in $C$. The tissue was successively stimulated with five different peptides (each at $10^{-9} \mathrm{M}$ ), followed by forskolin $(20 \mu \mathrm{M})$. Note that cells 1 and 2 each recognized two peptides with different anchor residues. The arrows indicate the time points at which stimulus application was turned on. Scale bars: $A, 200 \mu \mathrm{m} ; \boldsymbol{B}, \boldsymbol{C}, 10 \mu \mathrm{m}$.

C57BL/6 males display a strong preference in investigating BALB/c versus C57BL/6 urine (Fig. $6 B)(74.8 \pm 2.2$ vs $25.2 \pm$ $2.2 \% ; n=14 ; p<0.001)$.

Next, we tested whether C57BL/6 males (preoperative) display a preference in investigating $\mathrm{C} 57 \mathrm{BL} / 6$ urine supplemented with peptides specific for BALB/c as opposed to C57BL/6 haplotypes. This was indeed the case (Fig. $6 C$, pre-op) $(67.8 \pm 3.9$ vs $32.2 \pm 3.9 \% ; n=12 ; p<0.01)$, indicating that the attractiveness of same-strain urine can be enhanced by the addition of disparate MHC peptides. Importantly, this preference did not require a functional VNO, because it was still evident in the same C57BL/6 animals after surgical removal of the $\mathrm{VNO}$ (Fig. 6C, VNX) $(62.0 \pm 5.0$ vs $38.0 \pm 5.0 \% ; n=12 ; p<0.01)$. Complete removal of the VNO was proven in histological sections of the main and accessory olfactory bulb by specific labeling of intact vomeronasal nerve fibers with HRP-SBA (Wysocki and Wysocki, 1995; Pankevich et al., 2004). Sham-operated control mice $(n=3)$ showed heavy HRP-SBA staining at the AOB level, whereas no staining was observed in VNX animals $(n=12)$ (Fig. $6 F$ ). A potential caveat of the results in Figure $6 C$ is that the tests using VNX mice were performed with animals that had undergone previous testing. Naive animals might be more VNO dependent. However, the data shown in Figure $6 G$ argue against this.
To control for potential changes in the release of urine volatiles after addition of the peptides to urine, we used the same paradigm as in Figure 6C ("pre-op") under conditions that precluded direct physical access to the cotton tips without posing a barrier for the volatiles ("caged stimuli"; see Materials and Methods). No preference was observed in this case (Fig. $6 D)(45.2 \pm 3.2$ vs $54.8 \pm 3.2 \% ; n=14$; $p=0.16)$, ruling out that the presence of MHC peptides somehow affects release of urine volatiles.

To demonstrate that $\mathrm{H}-2 \mathrm{~K}^{\mathrm{d}}$ peptides are not attractive per se but that this function depends on a combination with an animal's own genotype, we performed the preference test in Figure $6 C$ (pre-op) with BALB/c males (Fig. 6E). These animals showed a clear preference for samestrain urine supplemented with peptides specific for $\mathrm{C} 57 \mathrm{BL} / 6$ as opposed to BALB/c haplotypes $(64.1 \pm 4.9$ vs $35.9 \pm$ $4.9 \% ; n=12 ; p<0.01)$. Together, these results indicate that male mice display a social preference for disparate $\mathrm{MHC}$ peptides and that this preference does not require a functional VNO.

To further determine whether this effect depends on peptide recognition by the main population of OSNs in the MOE, we used mice deficient for the CNGA2 gene. Here, we observed a significant preference for disparate peptides in CNGA2 $2^{+/ 0}$ $(70.5 \pm 5.3$ vs $29.5 \pm 5.3 \% ; n=12 ; p<$ $0.01)$ but not in $C N G A 2^{-/ 0}(54.2 \pm 5.9$ vs $45.8 \pm 5.9 \% ; n=12 ; p=0.33)$ mice (Fig. 6G).

All of these averaged behavioral results were fully supported by examining data from each individual mouse (supplemental Fig. 7, available at www.jneurosci.org as supplemental material). In these tests, we have added three exogenous peptide ligands to urine, each at a final concentration of $12.5 \mu \mathrm{M}$ (see Materials and Methods). Importantly, our results also show that, under the conditions of the preference paradigm used here, mice are still capable of displaying a preference when the concentration of the peptide mixture was decreased by 10 -fold (supplemental Fig. 8, available at www.jneurosci.org as supplemental material). Thus, on the basis of these findings, we conclude that detection of MHC peptides by OSNs in the MOE is biologically relevant for the display of a social preference in male mice and that this effect depends critically on an intact CNGA2 gene.

\section{Discussion}

A primary goal of this study was to determine whether the mouse main olfactory system is capable of recognizing MHC peptide ligands. The data presented here show that MHC peptide ligands can gain access to the MOE during direct physical contact with a conspecific and that these molecules function as olfactory cues for sensory neurons in mouse MOE. Our results demonstrate that subsets of OSNs detect MHC class I peptides at remarkably low concentrations using an evolutionary conserved signal transduction mechanism that involves cAMP formation and the 
CNGA2 and CNGA4 channel genes. We provide evidence that, in behaving mice, this MOE-dependent detection of MHC peptide information is used for decision making in a social preference test. The results provide strong support for the proposal that MHC peptide ligands, in addition to their established role in the immune system, function as social recognition cues during conspecific communication, providing unique olfactory signatures to an individual (Leinders-Zufall et al., 2004; for review, see Boehm and Zufall, 2005). Our findings support a conceptual model in which the detection of conspecific chemical recognition signals via the main olfactory system plays important roles in the regulation of mammalian social behavior.

\section{Access of nonvolatile cues to the MOE}

A prerequisite for peptide recognition by the MOE is that these cues reach the olfactory mucosa in natural behavioral situations. A widely held view is that odorants must be sufficiently volatile to be detected by the MOE. We have used a nonvolatile fluorescent marker to demonstrate that nonvolatile molecules in urine gain access to the MOE of freely behaving mice during social investigatory behaviors that involve direct physical contact. Our results are supported by previous reports that showed transport of rhodamine-supplemented female urine halfway up the nasal septum of male guinea pigs (Wysocki et al., 1980) and uptake of HRP (40 kDa) to all areas of the MOE in male hamsters (Meredith, 1983; Meredith and O'Connell, 1988). We therefore conclude that, after direct physical contact with the stimulus source, nonvolatile constituents present in urine and other bodily secretions not only gain access to the VNO but also to the MOE.

\section{High sensitivity of the mouse MOE}

A finding of importance is that subsets of OSNs detect MHC peptides at surprisingly low concentrations. Field potential doseresponse curves show $\mathrm{EC}_{50}$ values near $10^{-10} \mathrm{M}$, and single OSNs respond to nanomolar doses of peptides with a $\mathrm{Ca}^{2+}$ rise. For comparison, we used a volatile constituent of mouse urine, 2-heptanone, and showed that this compound also evokes MOE field potentials at $10^{-10} \mathrm{M}$. Although for many odors the dose-response curves in single OSNs have relatively elevated $\mathrm{EC}_{50}$ values, in the range 10-100 $\mu \mathrm{M}$ (summarized by Firestein, 2001), our results are supported by a growing body of evidence indicating that the mammalian MOE may detect some odor ligands at much lower concentrations than previously thought (Shepherd, 2004). For example, in accord with our findings, the olfactory receptor
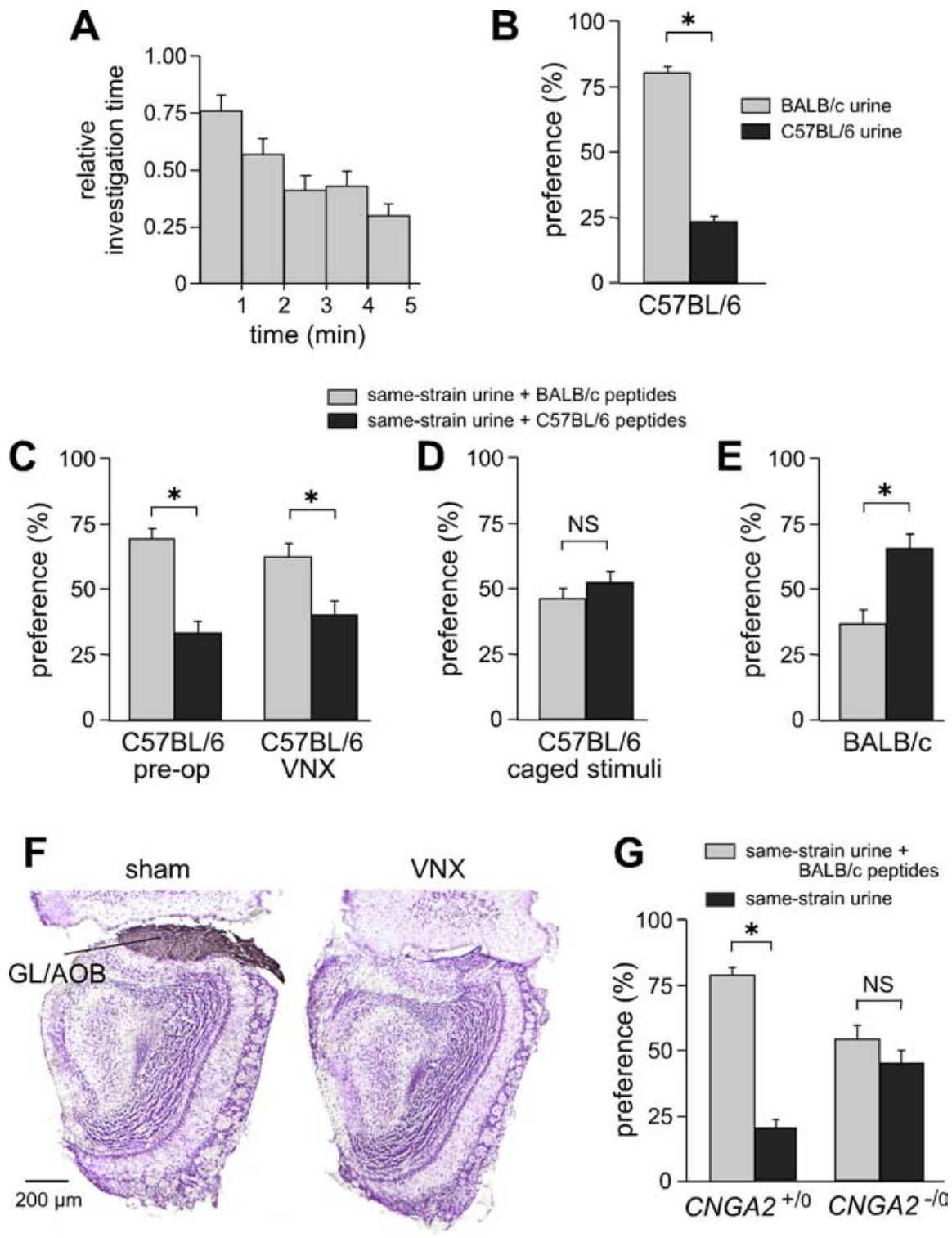

Figure 6. Essential role of the main olfactory system and the CNGA2 channel subunit in the display of a social preference for disparate MHC class I peptides in male mice. $A$, Relative investigation time (means \pm SEM) in the cotton-tip test plotted as a function of time. Bin width, $1 \mathrm{~min}$. Data are based on results from animals $15-26$ (preoperative) and $41-52$ (see supplemental Fig. 7 , available at www.jneurosci.org as supplemental material, for individual mice). For each individual animal, the investigation time per $1 \mathrm{~min}$ bin was measured and normalized to the maximum value. $B$, Preference of $C 57 \mathrm{BL} / 6$ males for urine obtained from BALB/C (gray) versus C57BL/6 (black) female mice $\left[F_{(1,27)}=124.1\right.$; Student-Newman-Keuls (SNK) test; $\left.{ }^{*} p<0.001\right]$. C, Prefer-

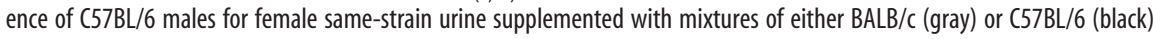
peptides. A preference for disparate peptides was observed in preoperative (pre-op) and VNX mice $\left(F_{(1,47)}=29.5 ; \mathrm{SNK}\right.$; ${ }^{*} p<$ 0.01 ) with no significant effect of surgical VNX (SNK; $p=0.43$ ). $\boldsymbol{D}$, When direct physical contact is precluded (caged stimuli), C57BL/6 males do not show a preference for female same-strain urine supplemented with mixtures of BALB/C (gray) versus $\mathrm{C} 57 \mathrm{BL} / 6$ (black) peptides $\left(F_{(1,27)}=2.3 ; \mathrm{SNK}^{\mathrm{NS}} p=0.16\right)$. $\boldsymbol{E}$, Preference of $\mathrm{BALB} / \mathrm{C}$ males for female same-strain urine supplemented with $C 57 \mathrm{BL} / 6$ (black) versus BALB/c (gray) peptides $\left(F_{(1,23)}=10.0 ; \mathrm{SNK}^{*} p<0.01\right) . \boldsymbol{F}$, Representative images of coronal sections through the main and accessory olfactory bulb of sham-operated and VNX mice. Sections were stained with HRP-SBA. The absence of HRP-SBA labeling in the accessory olfactory bulb of VNX animals signifies the complete removal of the VNO. GL/AOB, Glomerular layer of the accessory olfactory bulb. G, Preference of $C N G A 2^{+/ 0}$ and $C N G A 2^{-10}$ males for female same-strain urine supplemented with BALB/c peptides (gray) or solvent (black). $C N G A 2^{+/ 0}$ but not $C N G A 2^{-10}$ mice displayed a significant preference for disparate peptides $\left(F_{(1,47)}=11.1 ; \mathrm{SNK}^{*} p<0.01 ;{ }^{\mathrm{NS}} p=0.33\right)$.

OR912-93 recognizes 10 nM 2-heptanone when expressed in a heterologous cell system (Gaillard et al., 2002). Likewise, in vivo imaging of glomerular activity in the mouse main olfactory bulb has revealed detection of short aliphatic odor molecules in the low nanomolar range (Bozza et al., 2004). It is not yet clear why the MOE exhibits high-sensitivity responses in some studies but 
not in others. These discrepancies could reflect differences in the recording methods (i.e., dissociated cells vs more intact preparations) or they could reflect the fact that it is often difficult to identify a preferred ligand for a given OSN.

\section{Identity of peptide-sensitive OSNs}

Although our imaging results reveal for the first time the existence of individual peptide-sensitive OSNs in the mammalian MOE, we cannot yet determine the molecular identity of these cells. Ciliated neurons of the MOE comprise a heterogeneous population, with subgroups of cells displaying unique patterns of gene expression (Zufall and Munger, 2001). One such group expresses a receptor guanylyl cyclase, GC-D (Fülle et al., 1995; Meyer et al., 2000). These cells do not express CNGA2 but rather the cGMP-specific CNGA3 channel, ruling out an involvement in the responses shown here. Another intriguing OSN subpopulation, defined by the expression of members of the OR37 subfamily, occupies a characteristic location on endoturbinate IIb (Strotmann et al., 2000). Our mapping results (Fig. 3) argue against a predominant role for OR37-expressing OSNs in MHC peptide responses. Collectively, our results show that peptiderecognizing OSNs differ in several important aspects from peptide-detecting VSNs (Leinders-Zufall et al., 2004), including the sensitivity, the signal transduction pathway, and the specificity. Detection thresholds in VSNs are approximately two orders of magnitude lower compared with those of OSNs, and peptide recognition in OSNs, unlike VSNs, involves the canonical cAMP second-messenger pathway. There are also clear differences in the specificity to MHC peptides in both types of cells. Whereas VSNs do not respond to elevated concentrations of MHC peptides in which the characteristic anchor residues are mutated (LeindersZufall et al., 2004), such peptides can be recognized by OSNs (Figs. 2, 5). Although our imaging results suggest a combinatorial scheme for the detection of MHC peptides by OSNs, we do not yet know the exact rules of this mechanism. Deciphering the precise tuning properties of peptide-sensitive OSNs and VSNs and identifying the receptors involved in peptide recognition remains a major goal of future research. On the basis of the considerations presented here, it seems unlikely that the same receptors are used for peptide recognition in both the MOE and VNO. It should be interesting to determine whether these receptors belong to family A (such as ORs) or family C (such as V2Rs) of G-protein-coupled receptors (GPCRs), or even other yet unknown receptor families. In this respect, it is important to note that, among known family A GPCRs, peptide receptors form a large subgroup and mediate important physiological roles of endogenous signaling peptides (Kristiansen, 2004).

\section{Peptide recognition and the dual olfactory hypothesis}

In the traditional view, known as the dual olfactory hypothesis (Scalia and Winans, 1975), the main and accessory olfactory systems form separate and parallel pathways presumably involved in the detection of distinct sets of olfactory cues (summarized by Halpern, 1987). For example, the accessory system has been widely thought to detect nonvolatile pheromones that trigger behavioral and endocrine responses, whereas the main system has generally been regarded as a nonselective molecular analyzer of volatile odorants. In contrast, a growing body of evidence suggesting far greater integration and complexity of chemosensory detection of both systems has challenged this classical view (Meredith, 1998; Xu et al., 2005, and references therein). Our results support and extend this notion by demonstrating that olfactory recognition of MHC peptides in mice occurs through both the main and accessory olfactory system. This result, however, does not mean that the functions of both systems are redundant. In fact, our behavioral data provide direct evidence for distinct functions of the two olfactory pathways in different behavioral contexts. For instance, detection for disparate $\mathrm{MHC}$ peptides in the social preference test depends on CNGA2 function in the MOE but is independent of a functional VNO (Fig. 6). In contrast, $\mathrm{MOE}$-dependent peptide recognition in the absence of a functional VNO was not sufficient to influence the outcome of the pregnancy-block paradigm (Kelliher et al., 2005). Therefore, it appears that the same social cues may mediate different conspecific behaviors through the activation of each system. We note that our results do not exclude the role of other, particularly volatile chemosignals in behavioral decisions in mice (Restrepo et al., 2004). Indeed, a male mouse urinary volatile that can be detected by the main olfactory system has recently been shown to enhance urine attractiveness to females (Lin et al., 2005). The exact concentration of MHC peptides in urine is currently unknown. Urine might contain hundreds of peptide sequences that might be constitutive or inducible (i.e., vary over time depending on hormonal cycling, maturation stage, and other factors) (Boehm and Zufall, 2005). It is also unclear whether urine is the only source of MHC peptide ligands or whether peptides from other bodily secretions (Kimoto et al., 2005) contribute to social preference in mice. Thus, care must be taken when comparing the results from the preference test to what may occur in a real biological setting. It seems likely that social recognition under natural circumstances is vastly more complex than our controlled testing paradigm and probably involves the combined detection and integration of a variety of classes of chemosignals (Boehm and Zufall, 2005).

\section{Outlook}

Our results are of direct relevance to previous studies (Wedekind et al., 1995; Jacob et al., 2002) on the role of MHC-related odors in human behavioral decisions. Our finding that MHC peptide ligands can gain access to and be recognized by sensory neurons of the MOE will prompt further investigations aimed at understanding whether evolutionary conserved MHC peptide ligands also function as odor signals in humans.

\section{References}

Beauchamp GK, Yamazaki K (2003) Chemical signalling in mice. Biochem Soc Trans 31:147-151.

Boehm T, Zufall F (2006) MHC peptides and the sensory evaluation of genotype. Trends Neurosci, in press.

Boehm T, Bleul CC, Schorpp M (2003) Genetic dissection of thymus development in mouse and zebrafish. Immunol Rev 195:15-27.

Boschat C, Pélofi C, Randin O, Roppolo D, Lüscher C, Broillet MC, Rodriguez I (2002) Pheromone detection mediated by a V1r vomeronasal receptor. Nat Neurosci 5:1261-1262.

Bozza T, McGann JP, Mombaerts P, Wachowiak M (2004) In vivo imaging of neuronal activity by targeted expression of a genetically encoded probe in the mouse. Neuron 42:9-21.

Brennan PA, Keverne EB (2004) Something in the air? New insights into mammalian pheromones. Curr Biol 14:R81-R89.

Buck LB (2000) The molecular architecture of odor and pheromone sensing in mammals. Cell 100:611-618.

Chen S, Lane AP, Bock R, Leinders-Zufall T, Zufall F (2000) Blocking adenylyl cyclase inhibits olfactory generator currents induced by " $\mathrm{IP}_{3}$ odors.” J Neurophysiol 84:575-580.

Dedier S, Reinelt S, Rion S, Folkers G, Rognan D (2001) Use of fuorescence polarization to monitor MHC-peptide interactions in solution. J Immunol Methods 255:57-66.

Firestein S (2001) How the olfactory system makes sense of scents. Nature 413:211-218. 
Fülle HJ, Vassar R, Foster DC, Yang RB, Axel R, Garbers DL (1995) A receptor guanylyl cyclase expressed specifically in olfactory sensory neurons. Proc Natl Acad Sci USA 92:3571-3575.

Gaillard I, Rouquier S, Pin JP, Mollard P, Richard S, Barnabe C, Demaille J, Giorgi D (2002) A single olfactory receptor specifically binds a set of odorant molecules. Eur J Neurosci 15:409-418.

Halpern M (1987) The organization and function of the vomeronasal system. Annu Rev Neurosci 10:325-362.

Jacob S, McClintock MK, Zelano B, Ober C (2002) Paternally inherited HLA alleles are associated with women's choice of male odor. Nat Genet 30:175-179.

Kelliher KR, Ziesmann J, Munger SD, Reed RR, Zufall F (2003) Importance of the CNGA4 channel gene for odor discrimination and adaptation in behaving mice. Proc Natl Acad Sci USA 100:4299-4304.

Kelliher KR, Spehr M, Li XH, Zufall F, Leinders-Zufall T (2005) Relative roles of the main and accessory olfactory systems in behavioral responses to MHC class I peptides: Bruce effect. Chem Senses 30:A18.

Keverne EB (2004) Importance of olfactory and vomeronasal systems for male sexual function. Physiol Behav 83:177-187.

Kimoto H, Haga S, Sato K, Touhara K (2005) Sex-specific peptides from exocrine glands stimulate mouse vomeronasal sensory neurons. Nature 437:898-901.

Kristiansen K (2004) Molecular mechanisms of ligand binding, signaling, and regulation within the superfamily of G-protein-coupled receptors: molecular modeling and mutagenesis approaches to receptor structure and function. Pharmacol Ther 103:21-80.

Leinders-Zufall T, Lane AP, Puche AC, Ma W, Novotny MV, Shipley MT, Zufall F (2000) Ultrasensitive pheromone detection by mammalian vomeronasal neurons. Nature 405:702-796.

Leinders-Zufall T, Brennan P, Widmeyer P, Chandramani PS, Maul-Pavicic A, Jäger M, Li X-H, Breer H, Zufall F, Boehm T (2004) MHC class 1 peptides as chemosensory signals in the vomeronasal organ. Science 306:1033-1037.

Lin DY, Zhang SZ, Block E, Katz LC (2005) Encoding social signals in the mouse main olfactory bulb. Nature 434:470-477.

Lin W, Arellano J, Slotnick B, Restrepo D (2004) Odors detected by mice deficient in cyclic nucleotide-gated channel subunit A2 stimulate the main olfactory system. J Neurosci 24:3703-3710.

Lucas P, Ukhanov K, Leinders-Zufall T, Zufall F (2003) A diacylglycerolgated cation channel in vomeronasal neuron dendrites is impaired in TRPC2 mutant mice: mechanism of pheromone transduction. Neuron 40:551-561.

Ma M, Shepherd GM (2000) Functional mosaic organization of mouse olfactory receptor neurons. Proc Natl Acad Sci USA 97:12869-12874.

Meredith M (1983) Sensory physiology of pheromone communication. In: Pheromones and reproduction in mammals (Vandenbergh JG, ed), pp199-252. San Diego: Academic.

Meredith M (1991) Sensory processing in the main and accessory olfactory systems: comparisons and contrasts. J Steroid Biochem Mol Biol 39:601-614.

Meredith M (1998) Vomeronasal, olfactory, hormonal convergence in the brain. Cooperation or coincidence? Ann NY Acad Sci 855:349-361.

Meredith M, O'Connell JR (1988) HRP uptake by olfactory and vomerona- sal receptor neurons: use as an indicator of incomplete lesions and relevance for non-volatile chemoreception. Chem Senses 13:487-515.

Meyer MR, Angele A, Kremmer E, Kaupp UB, Müller F (2000) A cGMPsignaling pathway in a subset of olfactory sensory neurons. Proc Natl Acad Sci USA 97:10595-10600.

Mombaerts P (2004) Genes and ligands for odorant, vomeronasal and taste receptors. Nat Rev Neurosci 5:263-278.

Munger SD, Lane AP, Zhong H, Leinders-Zufall T, Yau KW, Zufall F, Reed RR (2001) Central role of the CNGA4 channel subunit in $\mathrm{Ca}^{2+}$. calmodulin-dependent odor adaptation. Science 294:2172-2175.

Pankevich DE, Baum MJ, Cherry JA (2004) Olfactory sex discrimination persists, whereas the preference for urinary odorants from estrous females disappears in male mice after vomeronasal organ removal. J Neurosci 24:9451-9457.

Penn D, Potts W (1998) How do major histocompatibility complex genes influence odor and mating preferences? Adv Immunol 69:411-436.

Rammensee HG, Bachmann J, Stefanovic S (1997) MHC ligands and peptide motifs. Georgetown, TX: Landes Bioscience.

Restrepo D, Arellano J, Oliva AM, Schaefer ML, Lin W (2004) Emerging views on the distinct but related roles of the main and accessory olfactory systems in responsiveness to chemosensory signals in mice. Horm Behav 46:247-256.

Reusch TBH, Häberli MA, Aeshlimann PB, Milinski M (2001) Female sticklebacks count alleles in a strategy of sexual selection explaining MHC polymorphism. Nature 414:300-302.

Scalia F, Winans SS (1975) The differential projections of the olfactory bulb and the accessory olfactory bulb in mammals. J Comp Neurol 161:31-55.

Shepherd GM (2004) The human sense of smell: are we better than we think? PLoS Biol 2:E146.

Singh PB, Brown RE, Roser B (1987) MHC antigens in urine as olfactory recognition cues. Nature 327:161-164.

Strotmann J, Conzelmann S, Beck A, Feinstein P, Breer H, Mombaerts P (2000) Local permutations in the glomerular array of the mouse olfactory bulb. J Neurosci 20:6927-6938.

Wedekind C, Seebeck T, Bettens F, Paepke AJ (1995) MHC-dependent mate preferences in humans. Proc R Soc Lond B Biol Sci 260:245-249.

Wysocki CJ, Wysocki LM (1995) Surgical removal of the mammalian vomeronasal organ and its verification. In: Experimental cell biology of taste and olfaction: current techniques and protocols (Spielman AI, Brand JG, eds), pp 49-57. New York: CRC.

Wysocki CJ, Wellington JL, Beauchamp GK (1980) Access of urinary nonvolatiles to the mammalian vomeronasal organ. Science 207:781-783.

Xu F, Schaefer M, Kida I, Schafer J, Liu N, Rothman DL, Hyder F, Restrepo D, Shepherd GM (2005) Simultaneous activation of mouse main and accessory olfactory bulbs by odors or pheromones. J Comp Neurol 489:491-500.

Zhao H, Reed RR (2001) X inactivation of the OCNC1 channel gene reveals a role for activity-dependent competition in the olfactory system. Cell 104:651-660.

Ziesmann J, Ma W, Novotny MV, Zufall F, Leinders-Zufall T (2002) Combinatorial pheromone coding visualized in the mouse main olfactory epithelium. Chem Senses 27:A34.

Zufall F, Munger SD (2001) From odor and pheromone transduction to the organization of the sense of smell. Trends Neurosci 24:191-193. 